\author{
Artur Antoni Kasprzak ${ }^{1}$ \\ Cardinal Stefan Wyszyński University in Warsaw \\ Faculty of Theology
}

\title{
A Complicated 'Denominator' of the Beginnings of the History of the Charismatic Renewal in the Roman Catholic Church ${ }^{2}$
}

Every story has its beginning. Most stories have their end. An attempt at a synthetic analysis of the history of the beginning of the Charismatic Renewal in the Roman Catholic Church turns out to be confronted with a certain initial reality: not only does this history not have a specific beginning, but it also has no end. It is a story that is still open. In celebrating its fiftieth birthday in the Roman Catholic Church recently (2017), a symbolic experience was taken as the original reference date. The receipt of charisms by members of a small group of American students on 18 February 1967, in Pittsburgh (Pennsylvania) in the United States, is a date and place that is in a sense only symbolic. Neither that moment nor that event exhausts the vast and much broader charismatic experience of the Holy Spirit in the Church, which can be seen in various and numerous moments in the history of the Church. This study efforts to explain this singular experience from the perspective of analysing the essential elements of the first structuring of the Charismatic Renewal in the Roman Catholic Church in the $20^{\text {th }}$ century. The study is also an attempt at a synthetic look at the history, but also at its authors, including Ralph Martin, Steve Clark, Gerry Rauch, Veronica O’Brien, Cardinal Léon-Joseph Suenens and Pope Paul VI.

\footnotetext{
${ }^{1}$ Rev. Artur Antoni Kasprzak, Doctor of Science — priest of Kalisz diocese, professor at WT UKSW in Warsaw; e-mail: a.kasprzak@uksw.edu.pl. ORCID: 0000-0001-9715-9357.

2 The text of the article was presented as an invited lecture at the international conference "On the Waves of the Spirit. Challenges of Pentecostalism", 4 June 2019 at the College of Theology and Social Sciences in Warsaw.
} 
Strictly theological and historical analyses indicate that the reality of charismatic renewal has existed continuously since the beginning of Christianity. It is assumed, however, that the Charismatic Renewal in the Catholic Church has existed since February 18, 1967, and that it is a so-called 'new rebirth'. However, the experience referred to as the new birth or the so-called 'New Pentecost' requires clarification. In a theological sense, these terms refer to a reality that has existed from the very beginning of Christianity. Each time it is about a certain 'new' intensity of experiencing God's grace in the Church, which the Church understands essentially as a re-actualisation of God's grace given in the sacrament of Holy Baptism. ${ }^{3}$

The discovery of this new intensity appears in the Church from time to time. In this article we are interested in a synthetic answer to the question: in what way have the lay faithful, as well as the hierarchy, in the recent history of the Church discovered this special grace of the Holy Spirit Renewal in their personal lives and, at the same time, in what way have they given it its first understanding and structure of coordination in the Roman Catholic Church? Let us note that the experience of this charismatic renewal of life is not just the experience of a small group of people today. It is enjoyed today by several percent of all the faithful of the Catholic Church $(11.2 \%$ in 2000$) .^{4}$

Despite the vastness of this phenomenon, the reality of Renewal in the Holy Spirit seems to transcend structural and temporal understanding. This calls for a specific methodology to capture its essence. What is the key to understanding the origins of the history of the Charismatic Renewal movement in the Roman Catholic Church? In response to this question, various types of analysis are most often proposed, which start from the perspective of some chosen point of view, or even from the perspective of vague hypotheses of spiritual interpretation of the development of the Church. In order to avoid the reproach of ahistoricity or the attempt to create some polemical vision of ecclesiology, ${ }^{5}$ in this study we propose to highlight a history of interconnected facts that today can already be considered as indisputable elements of a common denominator in defining the Charismatic Renewal in the Roman Catholic Church.

Here we highlight characteristic six points: 1. a properly implemented ecumenism, 2. pastoral care to direct the spiritual experience towards the heart of the Church, 3. the creation of a framework of institutional accompaniment by

\footnotetext{
${ }^{3}$ See: A.A. Kasprzak, Teologiczne podstawy Odnowy w Duchu Świętym w ujęciu kardynała Léona Josepha Suenensa, WT UAM, Poznań 1999, p. 89.

${ }^{4}$ D. Barett, T.M. Johnson, The Catholic charismatic Renewal, 1959-2025 [in:] 'Then Peter stood up. 'Collection of the Popes' Addresses to the Catholic Charismatic Renewal from its origin to the year 2000, ed. by O. Pesare, ICCRS, Rome 2000, p. 117.

${ }^{5}$ For example, the claim that the Charismatic Renewal was an answer to the prayer of Pope Leo XIII, but that this answer resulted in the establishment of the Pentecostal Church.
} 
the episcopate, 4. the editing of the theological basis for the Church's first understanding of the grace received, 5. the blessing of the Pope, and finally, 6. the institutional and juridical recognition by the Church of the Charismatic Renewal. Undoubtedly, the key to linking all these elements is the role that Cardinal LéonJoseph Suenens, Primate of Belgium, played for the Renewal. As this study will show, his action at the beginning of the Charismatic Renewal in the Roman Catholic Church is unique, and he, together with Veronica O'Brien, his long-time collaborator in the work of evangelisation, are its precursors.

\section{The Origin of the Charismatic Experience. Ecumenical Prayer and Intercessory Prayer with the Imposition on of Hands - in Unity with the Church}

As Cardinal Suenens wrote in his most important book on the Charismatic Renewal, published in 1974 under the title A New Pentecost? (Une nouvelle Pentecôte?):

This Renewal first came into being in the Catholic Church among students in Duquesne University, Pittsburgh, Pennsylvania, during the year 1967. At a time of social and religious crises throughout their own country and the world at large, some of these young people, reliving the impossibility of finding a human solution, met for a weekend of prayer and fasting to ask the grace of the Holy Spirit. $[\ldots]$ That weekend, for those who attended, proved to be, in the true sense of the word a new Pentecost. Nor had they gone to it unprepared. Many had read David Wilkerson's The Cross and the Switchblade. This small book, which has sold in many thousands, recounts the personal story of a minister who, with faith in the Holy Spirit and under His guidance, transformed spiritually some of the toughest gang members of New York's slums, healing many who were addicted to drugs and helping many others as they got out of prison.

They had also read together St. Paul and the Acts of the Apostles and some of them had recited, every day for a year, the Sequence from the Octave of Pentecost, 'Come, Holy Spirit'. [...]

The Spirit's response to them was an experience, over again, of what happened when the first disciples of the Lord were together in the Upper Room in Jerusalem. An amazing spiritual transformation took place in them. They spoke of a new awareness of the love of God such as they had not experienced before; of a desire to pray and glorify God; of an insatiable thirst for Scripture. Moreover, they felt power within them to bear witness to the risen Jesus. They talked of a 'baptism in the Holy Spirit' and of charisms given to them similar to those of which we read in the early Church. They did not consider this 'baptism in 
the Holy Spirit' as in a way a replacement of the sacraments of baptism and confirmation. ${ }^{6}$

The beginning of the story most firmly established in the minds of Catholics about the Charismatic Renewal is linked to the episode described here. Before the events of February 1967, involving Catholic students at Duquesne University, they had been wondering how they could revive their apostolic activity, which seemed to them, up to that time, to be ineffective. This group of people belonged to the University, which was under the patronage of the Holy Spirit. ${ }^{7}$ The desire to become more open to the Holy Spirit was motivated above all by the desire of two professors from this university. One was a professor of history and the other a lecturer in theology. As Patti Gallagher Mansfield explains in her book-testimony, titled As by a New Pentecost. The Dramatic Beginning of the Catholic Charismatic Renewal:

They felt the need for a greater inner dynamism, a new power to live as Christians and to give witness to Christ. Both men had been committed to the Lord for a number of years; both were cursillistas ${ }^{[8]}$ In fact, the history professor was instrumental in bringing the Cursillo Movement to Pittsburgh. Eileen Karl's testimony found later in this book gives greater detail on this point. They were also moderators of the Chi Rho Society on Duquesne's campus which one of them had founded years earlier to stimulate prayer, participation in the liturgy, Christian witness and social action. Yet they still wanted 'something more'. They weren't sure exactly what it was, but they made a pact to pray for one another.

Each day from the spring of 1966 on, they prayed that the Holy Spirit would renew in them all the graces of their Baptism and Confirmation, that He would fill up in them the vacuum left by human effort with the power and love of the Lord Jesus Christ. (...)

The National Cursillo Convention in August of 1966 was destined to be an important meeting for the two professors from Duquesne. It was there that they met up with their friends, Ralph Martin and Steve Clark. They were given copies of the two books about the Pentecostal experience and urged to read them, which they did. God had already been preparing them for a new dimension of life in the Spirit by awakening in them a deep spiritual hunger and leading them into concerted prayer. ${ }^{9}$

${ }^{6}$ L.-J. Suenens, A New Pentecost?, New York 1975, pp. 72-74.

${ }^{7}$ Duquesne University of the Holy Spirit. Cf. P. Gallagher Mansfield, Jakby nowa Pięćdziesiątnica. Początek katolickiej Odnowy w Duchu Świętym, tłum. J. Bartosik, Warszawa 1993, p. 65.

${ }^{8}$ The expression cursillistas from Spanish means a participant in the apostolic movement Cursillos de Cristiandad (literally Short Courses in Christianity). The movement was founded in 1944 in Majorca (Spain) by lay faithful.

9 P. Gallagher Mansfield, As by a New Pentecost: The Dramatic Beginning of the Catholic Charismatic Renewal, Phoenix 2016 $6^{2}$, pp. 34-35. 
The further description of the initial events explains their first intellectual understanding of the need for the Holy Spirit and the possibility of receiving the baptism in the Holy Spirit. The two professors tested this point by intensively studying the Scriptures. As Patti Mansfield further writes:

The professors were faced with several possibilities. They could continue praying and discussing this deeper life in the Spirit themselves, but that didn't seem too promising. They had already been praying and talking for some time. Perhaps they thought they should lay hands on each other and pray for a release of the Holy Spirit. They weren't convinced that this would be the best alternative either. Another option was to attend a Pentecostal church, but they were reluctant to do so. In the end, the most attractive alternative seemed to be to find some neo-Pentecostals, those who had remained within their own denominations after the Baptism in the Spirit. It was a bold step, but they decided to take it..$^{10}$

The first providential meeting between Catholic professors and Flo Dodge, a parishioner of Fr William Lewis of Christ Church in North Hills, Pittsburgh, took place on 13 January 1967. It was an intense prayer for the Baptism in the Holy Spirit. ${ }^{11}$ During a second prayer with the imposition of hands, on 20 January of the same year, the theology professor wrote:

They simply asked me to make an act of faith for the power of the Spirit to work in me. I prayed in tongues rather quickly. It was not a particularly soaring or spectacular thing at all. I felt a certain peace - and at least a little prayerful - and truthfully, rather curious as to where all this would lead. They broke out food afterwards and had a little party. I remember that my comment to them that night was, 'See what you do when you have Catholics here, you have rites and ceremonies'. They had never done that before. They had always sort of just broken up and gone home. That night, however, was a sort of celebration. ${ }^{12}$

In this, for us, the first constitutive element of the history of the beginnings of the Charismatic Renewal in the Roman Catholic Church, it seems necessary to emphasise two important points.

Firstly, we see in the history quoted here a very clear ecumenical context for the first experience of the Renewal in the Holy Spirit. Indeed, from the first moment of prayer for the grace of the so-called Baptism in the Holy Spirit by Catholics, it was not just about the sheer joy of the charisms received. Secondly,

\footnotetext{
${ }^{10}$ Ibid., p. 36.

${ }^{11}$ Ibid., p. 39.

12 Ibid., pp. 42-43.
} 
there has also been an element of extending this experience to others, and a freedom to strengthen each other in an ecumenical dimension. ${ }^{13}$ The group of Catholic students, despite being completely surprised by the gift of charisms, at the same time had no desire or even thought of converting to the Neopentecostal movement. The group did not share the idea of proselytism, present in the consciousness of many members of evangelical groups, that the experience of Baptism in the Holy Spirit, also called Rebirth in the Holy Spirit, would be synonymous with conversion to a new (implicitly the only correct) Christian denomination. The experience of the charisms, this first beginning of the Charismatic Renewal in the Roman Catholic Church, was accompanied from the very beginning by a correct understanding of ecumenism. It was also spontaneously and properly understood that the goal of the Holy Spirit's action was not the charisms themselves or the charismatic experience of God's action, but that it was necessary to live these gifts always in unity with the Church of one's membership. As far as unity between Christians of different denominations is concerned, it was also realised and accepted as something natural that it is the will of the Holy Spirit to convert within the framework of one's identity of faith and the structure of the Church. Undoubtedly, this correct understanding of ecumenism was the fruit of the recommendations of the Second Vatican Council implemented at that time. For the first Catholic charismatics of the time, the Council was a confirmation of the authenticity of their experience and an encouragement to further develop the graces received from the Holy Spirit. In the Council's perspective, Catholic believers did not need to have any fears about charisms or the ecumenism they were experiencing. ${ }^{14}$

To clarify the whole story, there is a second important element to be noted in this first experience of the charisms by American students. It is the extraordinary

${ }^{13}$ Reverend Don Basham received a letter from Jim Prophater, an artist present at the first meeting at Flo Dodge of the said two Catholic professors, and in it the following words of testimony:

'There has been such a tremendous move of the Holy Spirit here in Pittsburgh that it is making our heads swim - because we are right in the middle of it. Remember the two young instructors of theology from Duquesne who received the Holy Spirit at Flo's when you were here last? Well, the tallest of the two, went home that night so full of the Spirit that he was bursting. He told his wife about it - I guess until the wee hours of the morning — prayed for her and she received... Then they took thirty Duquesne students on a weekend retreat, for the purpose of studying the first four chapters of Acts. They had an upper room experience and twenty or more received the Holy Spirit. Back on campus they have been praying fellow classmates through to receive. They even called Bishop Wright and informed him of what is happening.

They recognize the need for instruction, and we have been helping them. Friday night we went to hear testimonies of some of the students... Nothing is impossible with God! But, He sure shakes us up sometimes when He moves so quickly and in such power...' ibid., p. 57.

${ }^{14}$ Cf. ibid. 
intensity of the spread of this experience. The grace of the Baptism in the Holy Spirit was received first by these professors, then by about 25 students, then by hundreds, and a few years later, by tens of thousands of faithful Catholics. The first National Congress of the Renewal in the Holy Spirit in the United States, which took place in 1967, gathered about a hundred people. And seven years later, in June 1974, at the Second International Congress in South Bend, over thirty thousand people from thirty-five countries attended. About seven hundred priests, fifteen bishops participated. The Assembly was presided over by Cardinal Léon-Joseph Suenens. This unprecedented increase in the number of people experiencing revival in the Holy Spirit testifies that it was also the fruit of a new understanding of witness in the Church, that it now belongs to the mission of every believer. As expressed in the Second Vatican Council's Dogmatic Constitution on the Church, the lay faithful not only can, but are obliged to participate 'in the salvific mission of the Church itself' by virtue of Baptism and Confirmation (see LG 33). Their particular vocation is 'to make the Church present and operative in those places and circumstances where only through them can it become the salt of the earth' (LG 33). The Council emphasizes: 'Thus every layman, in virtue of the very gifts bestowed upon him, is at the same time a witness and a living instrument of the mission of the Church itself "according to the measure of Christ's bestowal" (Eph 4:7)' (LG 33). The renewal in the Holy Spirit has been an opportunity to put into practice the recommendations of the Council. The joyful witness to the faith of the lay charismatics has since become something normal in the kaleidoscope of the Church's life.

\section{Léon-Joseph Suenens (1904-1996) and Veronica O'Brien (1905-1998): an Extraordinary Adventure of Many Years of Collaboration for the Renewal of the Roman Catholic Church. The Mission to Bring the Charismatic Renewal into the Heart of the Church}

Another important common denominator in the history of the Charismatic Renewal in the Roman Catholic Church is the history of the realization of one of the most important challenges of a dynamically expanding spiritual experience: its connection to the life of the Church. This involves the extremely difficult task of initial pastoral discernment. Renewal had to find its proper place in the Catholic Church. Numerous open questions arose: Is it merely a matter of adapting Renewal in the Holy Spirit to the structure of the Church? Or is there a need for an approach in which Renewal in the Holy Spirit is to become just one of the many movements of the Church? Or perhaps God's will is even greater: that the renewal in the Holy Spirit should become a fundamental expression of the renewal of the whole Church? 
These are the crucial questions of which the lay leaders of the first Charismatic Renewal groups in the United States were increasingly conscious. Because they really needed expert help in the complex task of discerning appropriate responses, they were open from the beginning to working with the bishops of their dioceses. In the meantime, wise and courageous pastoral guidance was becoming increasingly necessary for the universal Church as well. The Charismatic Renewal, which at first appeared in small groups or communities on the margins of important activities in the life of the Church, ${ }^{15}$ became more and more dynamic, and by the early 1970s its presence was already established in Europe and on other continents of the world. ${ }^{16}$

Cardinal Léon-Joseph Suenens played a providential role in this universal adaptation of the Church to the Renewal, as did Veronica O'Brien, an Irish evangelist. At the time of the emergence of the Charismatic Renewal, Cardinal Suenens

${ }^{15}$ In a research paper on the Church in France in the ' 60 s and ' 70 s, we make the following conclusion, which in a general way can be applied to many other countries at that time: 'The bishops in their [five-year] reports describe charismatic groups as an insignificant phenomenon, few in number and essentially separate from social involvement. We are inclined to think that this was due to the fact that the majority of French pastors had gone through the seminary formation of the Sulpician School and that it was a generation of pastors who were accustomed to repeating over and over again the same pastoral model, which, incidentally, had already been in place since the late 1920s, based exclusively on Catholic Action'. A.A. Kasprzak, Kościót a nowoczesność. Rozeznanie pastoralne przemian społeczno-kulturowych we Francji po Soborze Watykańskim II, Kraków 2018, pp. 443-444 (See also the opinion of Archbishop G. Defois on this issue, p. 26).

${ }^{16}$ The Charismatic Renewal has been emerging in France since the early 1970s. The first experience of charismatic prayer was brought from the United States to this country in 1970 by the couple Xavier and Brigitte Le Pichon, who founded the first prayer group in Brest. Fr H. Caffarel, the founder of the Equipes Notre Dame community, as well as the founders of the Community Emmanuel Hervé-Marie Catta and Pierre Goursat expressed interest in their experience and in their personal prayer for the Baptism in the Spirit. The first prayer group of Catholic Charismatics in Paris met in the crypt of the Saint-Sulpice Church in Paris. In September of that year, at the invitation of Prof. S. Nagy, Father A. de Monléon from France arrived in Poland, having received the consent of Cardinal Wojtyła to propagate the Charismatic Renewal in Poland. That same year, Fr Blachnicki established contact with the Ann Arbor community in the United States. The first Charismatic prayer group in Poland was founded in Poznań by Father Marian Piątkowski, who had previously participated in the Charismatic Vigil at the Vatican on the day of Pentecost in 1975. The pastor of the community at that time was Father Bronisław Dembowski. The Charismatic Renewal also reaches Asia. In India, the first prayer groups were established as early as 1979 through the Catholic Charismatic Bible Schools. Cf.: H.M. Catta; B. Peyrous, Ogień i nadzieja. Piotr Goursat. Założyciel wspólnoty Emmanuel, tłum. M. Bartnicka-Gustowska, Kraków 2008, p. 54; [S.A.], Powołanie do Wspólnoty Emmanuel. Formacja, Warszawa 2021, pp. 38-41. B. Dembowski, Wiatr wieje tam, gdzie chce. Z doświadczeń Odnowy w Duchu Świętym, Kraków 1998, p. 7. M. Hébrard, Charyzmatycy. Zarys historii Odnowy w Duchu Świętym. Fakty, postacie, wydarzenia, wspólnoty, tłum. T. Jania, Kraków 1994, p. 31. M. Nowicka, M. Nowicki, Upili się młodym winem. Poczatki Odnowy w Duchu Świętym w Polsce (1975-1979), Warszawa 2016², pp. 35, 70. L.-J. Suenens, Souvenirs et Espérances, Paris 1991, p. 205. 
was already a well-known leader of the Church in many parts of the world. The Archbishop of Malines-Bruxelles and Primate of Belgium was already associated with the Second Vatican Council as its main architect and courageous reformer of the Church. ${ }^{17}$ As for Veronica O'Brien, despite the complexity of her life story, ${ }^{18}$ she was a model lay person, committed to evangelisation. Formed first in the Legion of Mary, where she served as a Zelator for many years, in collaboration with Cardinal Suenens she devoted herself entirely to helping coordinate the Renewal in the Holy Spirit internationally. It is worth noting that many of the initiatives that came into being in the Charismatic Renewal through the action of Cardinal Suenens were in fact inspired by Veronica O'Brien. ${ }^{19}$

The thesis of the vital importance of these two figures in the mission to bring the Renewal in the Holy Spirit into the heart of the Roman Catholic Church has remarkable support from the public testimony of Pope Francis himself a few years ago. On 3 July 2015, at a meeting with members of the Italian Charismatic Renewal gathered in St Peter's Square in Rome, the Pope, mentioning Cardinal Suenens by name, called him 'the great protector of the Charismatic Renewal'. He also recalled the figure of Veronica O'Brian, describing her as a 'collaborator' of Cardinal Suenens and as someone who also 'enjoyed the trust and affection of Pope Paul V'. ${ }^{20}$ Honouring them, he then said:

${ }^{17}$ Cf. D. Donnelly, Author of Reform: The Cardinal Suenens Story [Documentary film], John Carroll University 1999.

18 Veronica O'Brien was a nun in the congregation of St. Clotilde between 1924 and 1935. In the context of the turbulence of living out her vocation and various disagreements with her superiors, by common discernment and her free will, O'Brien left the congregation on 8 December 1935. Her last place of ministry in the congregation was in Switzerland, in the village of Aigle. See: L.-J. Suenens, The Hidden Hand of God: The Life of Veronica O'Brien and Our Common Apostolate, Dublin 1994, pp. 26-35. Cf. id., Les imprévus de Dieu, Paris 1993, pp. 27-36.

${ }^{19}$ On the first copy, on the first page of the book The Hidden Hand of God... (the same book in French: Les imprévus de Dieu...), dedicated to Veronica O'Brien, Cardinal Suenens wrote in his handwriting 'With a homage from the author to the author. With immense thanks to the measure of Heaven. + L.-J. Card. Suenens.' At the bottom, Cardinal Suenens notes: '25 mars 1993. Fête de l'Annonciation et de FIAT. Rue du Bac. Paris' (A copy of the above sentence is included in my own materials).

${ }^{20}$ On the same day, 3 July 2015, the journalist Anita Bourdin wrote in a press note of the Vatican daily ZENIT (for the French version edition) that the Pope had paid homage to 'two founders of the Charismatic Renewal', giving further their brief biographies: 'Leo-Joseph Suenens (1904-1996), as defender of the Charismatic Renewal in the Catholic Church: he was one of the four moderators of the Second Vatican Council and Archbishop of Mechelen-Brussels (Belgium). Veronica O'Brien (1905-1998), the first member of the Legion of Mary, was active in the development of the Charismatic Renewal in Belgium, France and the United States. She was a special adviser to ICCRO (now ICCRS), the International Secretariat of the Renewal, which was based first in Brussels, in the residence of Cardinal Suenens, and then in Rome'. See: https://bit. ly/34id4st [accessed: 31.5.2019]. 
it is always good to recall the memory: the identity of Catholic Charismatic Renewal, from which the Association Renewal in the Spirit was born. I will do so with the words of Cardinal Leon-Joseph Suenens, great protector of Charismatic Renewal, as he describes it in the second book of his Memoirs.

In the first place he recalls the extraordinary figure of a woman who did so much at the beginning of Charismatic Renewal; she was his collaborator who also enjoyed the trust and affection of Pope Paul VI. I am referring to Veronica O'Brien: she was the one who asked the Cardinal to go to the United States to see what was happening, to see with his eyes what she considered the work of the Holy Spirit. It was then that Cardinal Suenens got to know Charismatic Renewal, which he described as a 'flow of grace,' and he was the key person to maintain it in the Church. In the Mass of Pentecost Monday in 1975, Pope Paul VI thanked him with these words: 'In the name of the Lord I thank you for having brought Charismatic Renewal into the heart of the Church. ${ }^{21}$

Pope Francis' evocation of Cardinal Suenens and V. O'Brien as key figures in the discovery of the Charismatic Renewal in the Roman Catholic Church requires clarification. As the Pope points out, it is indeed through the collaboration mentioned above with Veronica O'Brien that Cardinal Suenens makes his first contacts with the Charismatic Renewal. The full beginning of Suenens' discernment and interest in the Charismatic Renewal must be linked to the story of Veronica O'Brien's journey to the United States in February 1971. Veronica O'Brien, in a manner both 'unexpected and miraculous', as her longtime friend Yvette Dubois recalls, encountered the Charismatic Renewal for the first time at Fordham University. ${ }^{22}$ Veronica O'Brien probably received information about the Charismatics from Margaret F. Grace, a donor ${ }^{23}$ to Cardinal Suenens' many works of evangelisation. ${ }^{24}$ A year later, in November 1973,

${ }^{21} \mathrm{https} / / /$ bit.ly/2IQm00G [accessed: 15.12.2020].

${ }^{22}$ Yvette Dubois, a close friend and companion on Veronica O'Brien's various trips, notes in her memoirs: 'Mais voici d'une manière aussi imprévue que miraculeuse: la rencontre avec le RENOUVEAU... Dès février 1971, I ${ }^{\text {èr }}$ réunion à Fordham University. En novembre (elle= O'Brien) retourne aux USA avec Yvette à South Bend and Ann Arbor...'. Text dated 20.5.1979, private archives of Cardinal L.-J. Suenens, queried by Mgr Leo Declerck, e-mail dated 12.6.2019.

${ }^{23}$ Mrs Margaret Grace, as the widow of an American billionaire, supported many of Cardinal Suenens' reform initiatives in the Church. For example, at the end of the Second Vatican Council, she rented a palace called villa Miani in a prestigious area of Rome (Via Trionfale, 151, 00136 Roma), thus creating a comfortable environment for additional conferences under the auspices of Cardinal Suenens with superiors of congregations and religious orders, lay leaders and bishops from missionary countries. Cf. FConc. Suenens n 2922-2925.

${ }^{24}$ According to the memoirs of Mgr Wilfried Brieven, Cardinal Suenens' secretary, information about the existence of Catholic Charismatics (literally 'Catholic Pentakotists') was given to Veronica O'Brien by Mrs Margaret Grace during their meeting in New York in 1972: 'Ce n'est 
Veronica O'Brien and Yvette Dubois, on behalf of Cardinal Suenens, visited the first communities of Renewal in the Holy Spirit in several universities in the United States. In a book dedicated to Veronica O'Brien, Cardinal Suenens recalls her visit to Ann Arbor, Michigan, and to South Bend, Indiana. During a visit to a charismatic community in Ann Arbor, V. O'Brien experienced the Baptism in the Holy Spirit. ${ }^{25}$ In the meeting with the community, her first contact and long conversations with the leaders of the movement took place, especially with Ralph Martin. ${ }^{26}$

Veronica O'Brien, visiting less than a year later, in June 1973, the Episcopal community in Houston (Texas), which had pioneered the Renewal of that Christian denomination, spoke to the pastors present at an impromptu conference about the hope for ecumenical unity among all Christians. She then emphasised the special role of the Charismatic Renewal in this process. During the charismatic prayer she also spoke a message to Protestant leaders: 'Do not be afraid $[\ldots]$ to go to Rome and pray on the tombs of Peter and Paul. All ecumenical paths lead there. ${ }^{27}$ The prayerful message of the Irish evangelist undoubtedly stemmed from the context of the meeting itself: the spiritual quest for the unity of all Christians. The invitation was certainly also part of a specific intention, namely, to link the ecumenical experience of God that was taking place in the United States with the centre of the Roman Catholic Church, which was the Vatican and the Pope. A year earlier, Veronica O'Brien had had a personal audience with Pope Paul VI, during which the pope urged her to build unity in the Church in a special way. ${ }^{28}$ In the distant United States, this intention also had a certain prophetic quality. During the same prayer, Veronica O'Brien saw a spiritual picture of the future events connected with the Renewal: 'I see in my mind that one day Cardinal Suenens will welcome the pilgrims of the Charismatic Renewal to Rome, and will

qu'en 1972 que Veronica, lors d'une rencontre avec Margie Grace à New York a été informée de ce nouveau mouvement des "Pentecôtistes catholiques".' The meeting itself and its content are not in doubt. But as we have shown in our study, based on Yvette Dubois's recorded notes (see: supra note 22), Veronica O'Brien had visited Catholic charismatic groups in the United States before, in 1971. Query, e-mail of Rev. Mgr Wilfried Brieven dated 4.6.2019. Cf. L.-J. Suenens, Les imprévus de Dieu..., p. 210.

25 'I really and truly do feel that something special happened inside me on that famous evening when Yvette and I were baptised in the Spirit, at Ann Arbor. The general impression was one of ethereal lightness - as if there was a valve in my soul, and breathing into it made me all light and floating and happy.' L.-J. Suenens, The Hidden Hand of God..., p. 221. Cf. id., Les imprévus de Dieu..., p. 213.

${ }^{26}$ Cf.: id., Les imprévus de Dieu..., pp. 210-211. Id., The Hidden Hand of God..., p. 218.

${ }^{27}$ Id., The Hidden Hand of God..., p. 223.

28 Veronica O'Brien's audience with Pope Paul VI at the Vatican took place on 8 March 1972. See: L.-J. Suenens, Les imprévus de Dieu..., pp. 208-210. Cf. Query by the Rev. Leo Declerck, e-mail dated 12.6.2019. 
celebrate the Eucharist in St Peter's Basilica, on the occasion of Pentecost'.${ }^{29}$ Two years later this happened. Indeed, the presiding of the Mass on Pentecost Monday in St Peter's Basilica was proposed to Cardinal Suenens, and the initiative came from Pope Paul VI himself.

His first acquaintance with the new apostolic experience that was the Charismatic Renewal ${ }^{30}$ took place in close collaboration with Veronica O'Brien. It was she who paved the way for Cardinal Suenens' later repeated travels and meetings with various Charismatic Renewal leaders in the United States. The first such trip took place in 1973, when the Primate of Belgium went to meet, among others, the community in Ann Arbor and South Bend. ${ }^{31}$ It should be mentioned here that this experience falls in the post-conciliar years in the Roman Catholic Church, during which Suenens was extremely committed to promoting a programme of pastoral renewal and co-responsibility in the Church. A concept that became famous especially in English as 'co-responsibility and collegiality', Suenens proposed to use as a key to the hermeneutics of the Second Vatican Council. To this end, he even published a book in $1968^{32}$ and, a year later, an extensive interview on the same subject in Informations Catholiques Internationales. ${ }^{33}$ Cardinal Suenens very quickly saw in the Charismatic Renewal an action of the Holy Spirit which confirmed the implementation of the logic of the Second Vatican Council in the life

${ }^{29}$ L.-J. Suenens, The Hidden Hand of God..., pp. 223-224. Cf. id., Les imprévus de Dieu..., p. 215 (cf. pp. 219-220).

${ }^{30}$ Cardinal Suenens had many different apostolic engagements as a bishop. This is why the Canadian researcher, Rev. Prof. Gilles Routhier, compares him to an athlete who knew how to 'surf all the waves, [...] on the emblematic paths of the Church: as a legionary of Mary before Vatican II, as a struggler for co-responsibility in the post-conciliar years, as an ambassador of the Charismatic Renewal in the 1970s.' See: G. Routhier, Vatican II. Herméneutique et réception, Québec 2006, p. 31. Cf. A.A. Kasprzak, La Légion de Marie et la vision de l'Église tout entière en état de mission, idée maîtresse de la réflexion et de l'action du cardinal Léon-Joseph Suenens, ETL, 95 (2019) 1, pp. 97-117.

${ }^{31}$ Cardinal Suenens mentions that during his first visit to charismatic communities in the United States (in Ann Arbor and South Bend) he met 'a group of Frenchmen led by Pierre Goursat, the future founder of the Parisian community 'Emmanuel', who was in the USA on a study leave abroad.' L.-J. Suenens, Dar dla Kościoła, “Zeszyty Odnowy w Duchu Świętym” nr 16 (1997), p. 73. Cf.: L. Declerck, Catalogue des Archives Personnelles du cardinal L.-J. Suenens. (En dehors des papiers conciliaires et des papiers concernant la question du 'Birth Control'et de l'Encyclique 'Humanae Vitae'), 2003, Pro manuscripto. Consultation réservée, p. 112. L.-J. Suenens, Souvenirs..., pp. 214-215.

${ }^{32}$ L.-J. Suenens, La Coresponsabilité dans l'Église d'aujourd'hui, Bruges 1968, 224 pp.

${ }_{33}$ Id., L'unité de l'Église dans la logique de Vatican II [Interview accordée à José de Broucker], ICI 336 (15.05.1969), pp. I-XVI. Translation of the interview into Polish: id., Logiczne konsekwencje Soboru: Wywiad z kardynatem Suenensem, „Tygodnik Powszechny” 22 (1.VI.1969), pp. 1, 3-4. Cf. A.A. Kasprzak, La fameuse interview du cardinal Léon-Joseph Suenens du 15 mai 1969. L'appel aux medias pour promouvoir l'autorité coresponsable et collégiale de l'Eglise, ETL 92 (2016) 3, pp. 439-468. 
of the Church. In his view, God was realising through it a renewed vision of the Church as expressed by the Second Vatican Council. This was happening from below, that is, independently of the hierarchy in the Church, and it was indeed something like the grace of the Council, which was now received no longer by bishops but by all the faithful. ${ }^{34}$ Although generally yes, but in detail not entirely, this was the conviction shared with Cardinal Suenens by Pope Paul VI.

\section{The Uneasy Dialogue between Cardinal Suenens and Pope Paul VI on Finding a Suitable Place for the Renewal in the Holy Spirit in the Catholic Church}

The first conversation about the Charismatic Renewal and its significance for the Catholic Church with Pope Paul VI took place during the audience on Holy Thursday 1972. ${ }^{35}$ After the tension over Pope Paul VI's divergence of opinion from the post-conciliar interpretation of episcopal collegiality, Suenens makes clear his willingness to commit himself to a new dimension in the Church. He mentions the vital importance of the Charismatic Renewal for the Church. The day after his audience with the Pope, Suenens wrote to him:

${ }^{34}$ Cardinal Suenens refers to the link between the Second Vatican Council and the Charismatic Renewal at the beginning of his conference delivered on October 14, 1983, during his stay in Poland at the First National Congress of Charismatic Renewal. Here is an excerpt from a reflection Cardinal Suenens said at Jasna Góra:

'My brothers and sisters, if one wants to understand the Renewal that has united us here, one must understand the meaning of the Second Vatican Council. The Second Vatican Council was the grace of Pentecost at the level of the bishops. Pope John XXIII prayed in a special way for a new Pentecost, and Pope Paul VI repeated the same prayer: "Grant us, Lord, a new Pentecost, a new sending of the Spirit". John Paul II also repeats the same cry. We have received an immense grace of renewal for the Church.

The day after the Second Vatican Council something extraordinary happened in the Church: the breath of the Holy Spirit, which lasts and persists throughout the entire People of God. I believe that the Renewal should be seen in this perspective, that it is the Second Vatican Council that continues'. See: L.-J. Suenens, Dar Odnowy a postuga kapłana i zakonnika. I Ogólnopolski Kongres Odnowy w Duchu Świętym. Jasna Góra - Sala Papieska 14 X 1983. Cassette No. 4. p. A and B (comprehensive set prepared by Mr Jacek Fedorowicz) [in:] A.A. Kasprzak, Teologiczne podstawy Odnowy w Duchu Świętym w ujęciu kardynała Léona Josepha Suenensa ..., pp. 44-45 (for the full text of the conference see appendix p. 148, cf. CD: track no. 3).

${ }^{35}$ In his autobiography Souvenirs et espérances, Cardinal Suenens, publishing a letter of thanks to Pope Paul VI for the opportunity to have an audience and talk about the acceptance of the Charismatic Renewal as an experience of faith in Europe, notes the date 'Holy Thursday 1972'. L.-J. Suenens, Souvenirs et Espérances..., p. 205. 
As the general theme of my conferences [in the United States], I took up the following issue: the Church devoted an entire decade, 1960-1970, to looking explicitly at its 'institutional' aspect; the new decade, 1970-1980, requires us to emphasize the spiritual, 'pneumatic' aspect of the Church. This is what has allowed me to put aside 'at rest' structural problems in favour of joining in the question of a serious concern that I have found throughout the United States concerning: the desire to pray, to discover Jesus as a person, and the Holy Spirit.

In order to express what the 'charismatic' movement is in the Church in the United States, one would have to devote many pages, [of course] with various caveats and caution to the whole matter, but overall, the balance seems positive to me. ${ }^{36}$

Cardinal Suenens spoke with the Pope about the Renewal for the second time on February 19, 1973. During the audience he asked Paul VI if he knew the charismatic movement. Since the answer was negative, Suenens, explaining for half an hour the renewal he had already known personally, ${ }^{37}$ proposed at the end that the Pope himself should become involved in this new experience:

Shouldn't the Holy Father bring a charismatic prayer group, which by the way already exists in Rome, so that together with the professors of the Gregorian University they can pray in your chapel, in your presence? You would not have to do anything but listen to the faithful praying before you. This would give the Holy Father a very clear view. Encouraged by the good atmosphere, I insisted: 'Could not the Holy Father also invite some priest from the Renewal so that he would give a retreat on the occasion of Lent for the Roman Curia?'. ${ }^{38}$

The Primate of Belgium clearly encouraged Pope Paul VI to be more open to the experience of the Charismatic Renewal explained to him. Not for the first time, and not only in this matter, Cardinal Suenens seemed to be ahead of the Pope's initiative. He clearly sought the Pope's permission to personally attend the International Congress of the Leaders of the Renewal in the Holy Spirit, which, at the suggestion of Veronica O'Brien, was planned to be at Grottaferrata, near

${ }^{36}$ Ibid.

${ }^{37}$ Cardinal Suenens describes his first personal contact with the Charismatic Renewal in the United States (The first weekend experienced with the Charismatics was at Convent Station, under the direction of Father Jim Ferry. The second visit took place in Anna Arbor). Suenens indicates in his book that it was only on the basis of these personal contacts that he felt it necessary to share his new experiences with the Pope immediately. He asked Paul VI for an audience. From the logic of the description of events, one must conclude that Suenens' visit to the United States took place right at the beginning of 1973. See: L.-J. Suenens, Souvenirs et espérance..., pp. 214-215. Cf. L. Declerck, Catalogue..., p. 112.

${ }^{38}$ L.-J. Suenens, Souvenirs et espérance..., p. 216. 
Rome, and not at Porto Rico, far from the Vatican, as had been thought at the beginning. ${ }^{39}$ The intention of Suenens and the leaders of the Renewal in the Holy Spirit was to convince the Pope to endorse their experience more explicitly. However, the still unofficial leader of the Charismatic Renewal at that time did not receive Paul VI's permission to attend this Congress. ${ }^{40}$ Suenens' letter of 24 July 1973 is another attempt to change the Pope's decision. Suenens points to the urgent need for a pastoral response to the perceived challenge. ${ }^{41} \mathrm{He}$ stresses that 25,000 people, totally loyal and of goodwill to the "institutional" Church can gather without a shepherd. Suenens insists:

From the very beginning an appropriate policy of [pastoral] presence is needed. I would even say that this is a matter of urgency, while it is still relatively easy to give the appropriate guidelines, in which, moreover, the lay faithful are keenly interested. The temptation for a priest of a particular locality is to adopt an attitude of absence and observation with or without favour, under the pretext that the bishop is also observing and that he is awaiting guidance from Rome in this matter. This 'attitude of waiting and watching' cannot go on and on, and it can itself become the cause of possible errors when determining the tracks for further development. ${ }^{42}$

39 See: id., The Hidden Hand of God..., p. 225. Cf. id., Les imprévus de Dieu, "Bonne Nouvelle" VII-X (1993), p. 4.

${ }^{40}$ In July 1973, Cardinal Suenens received a letter from the Secretariat of State (dated 7.7.1973, reference number 238.212) in which Cardinal Giovanni Benelli, Assistant Secretary of State, points out: 'Sa Sainteté, cependant, estime qu'il ne serait pas opportune que la présence de votre Eminence vienne de quelque façon cautionner la réunion prévue à Rome pour le mois d'octobre prochain.' (G. Benelli, 'Monsieur le Cardinal', letter from Cardinal Benelli to Cardinal Suenens of 7.7.1973 [in:] Fonds L.-J. Suenens AAM, Charismatic Renewal, p. 2). The Primate of Belgium, writing back to Pope Paul VI (letter dated 24.7.1973), notes right at the beginning: 'Par une lettre de Mgr Benelli, j'ai appris que Votre Sainteté me priait de ne pas assister aux réunions privées qu'une soixantaine de dirigeants internationaux du «Renouveau Charismatique» vont tenir en octobre prochain à Grottaferrata. Il va sans dire que je m'incline devant un ordre, s'il est maintenu: le problème n'est pas là'. Cardinal Suenens explains to Pope Paul VI that his absence from the Grattaferrata meeting would have come as a shock to the leaders in question, who, as he still points out: 'qui souhaitaient me voir parmi eux pour les aider, sur place, à traduire leur désir de profonde communion avec le Saint-Père et avec l'Église.' (L.-J. Suenens, 'Très Saint Père', letter from Cardinal Suenens to Pope Paul VI, 24.7.1973 [in:] Fonds L.-J. Suenens AAM, Charismatic Renewal, p. 1).

${ }^{41}$ Roger Matthys, Cardinal Suenens' secretary during his retirement, wrote on the occasion of the new edition of the Malines Documents (see: the 2001 edition of the FIAT ed.): '[...] Certainly the ministerial Church does not have exclusivity on charisms, but it is up to the charism of the bishops to discern them. One of Cardinal Suenens' favourite sayings was: If the shepherds are not there, the wolves will come.' R. Matthys, Le Cardinal Suenens et le feu de la Pentecôte, 2 p. A4. Document in own archives.

${ }^{42}$ L.-J. Suenens, Très Saint Père..., pp. 1-2. Cf. the same text in: id., Souvenirs et espérance..., p. 218. 
Cardinal Suenens was instructed by the Pope to attend the congress and to celebrate the Eucharist just before it began. ${ }^{43}$ The Pope finally agreed to the Belgian primate's request and gave Suenens the opportunity to give a homily at the event, something he was very keen on. The First International Congress of Charismatics took place in Grottaferrata from October 8 to $11,1973 .{ }^{44}$ During the Congress, about fifteen charismatic leaders and two bishops from the United States (Bishop McKinney and Archbishop Hayes) were invited to a private audience with the Holy Father, Paul VI. ${ }^{45}$ A commemorative photo ${ }^{46}$ closed the first behind-thescenes difficulties in building a bridge between the Charismatic Renewal and the Vatican. The absence of Cardinal Suenens and Veronica O'Brian in the photo, however, may indicate the distance between Pope Paul VI and Cardinal Suenens that still existed at the time. A closer dialogue between them on the level of the Charismatic Renewal would only emerge in the following years.

${ }^{43}$ According to a letter from the Secretariat of State received by Cardinal Suenens from Cardinal G. Benneli on September 17, 1973, it appears that in July 1973 Suenens spoke personally with the Vice-Secretary of State regarding the International Conference of Charismatics in Grottaferrata. In his letter, Cardinal Benelli responds to the proposals Suenens offered him at that time, which included the appointment of Fr. Killian McDonnel to play the role of the intermediary between the Charismatic Movement and the Secretariat of State. In another matter, Cardinal Benelli, without mentioning by name but on behalf of the Pope, agreed that three important persons from the Charismatic community, as well as those accompanying them, indicated by Cardinal Suenens, could meet the Pope on the occasion of the Congress. However, he stresses: 'provided that such a favour does not imply some kind of official approval of the movement by the Holy Father.' The letter testifies that Cardinal Benelli was very sympathetic to Cardinal Suenens, noting indeed Suenens' personal engagement for the development of Charismatics in the Roman Catholic Church. Benelli, however, reminded Suenens that the Pope wanted to guarantee himself full freedom to make an important decision regarding the evaluation of the Charismatic movement, which has the characteristics of a Pentecostal movement: 'as I have already written in my letter of July 7, the Holy Father, looking with particular care at these experiences of the Pentecostal character, refrains for the time being from making any fundamental evaluation towards them.' G. Benelli, «Monsieur le Cardinal», letter from Cardinal G. Benelli to Cardinal L.-J. Suenens of 17.9 .1973 (reference number of the Secretariat of State n. 238971) [in:] Fonds L.-J. Suenens AAM, Charismatic Renewal, pp. 1-3.

${ }^{44}$ The Congress of Charismatics in Grottaferrata lasted exactly from Monday afternoon to Thursday evening. See: Fonds L.-J. Suenens AAM, Charismatic Renewal, doc. entitled 'Conference schedule', p. 1. Cf. D. Tomczyk, Kościól katolicki wobec ruchu odnowy charyzmatycznej, "Collectanea Theologica" 57/1 (1987), p. 47.

${ }^{45}$ Among the leaders, well-known figures such as J. Mckinney (USA), Br. A. Montleon OP (France) and Prof. H. Mühlen (Germany). Cf. L.-J. Suenens, Les imprévus de Dieu. "Bonne Nouvelle" VII-X (1993), p. 4. The text of Pope Paul VI's address to the participants in this congress is quoted by L.-J. Suenens: Nowe zesłanie Ducha Świętego?, Poznań 1988, pp. 90-91. Cf. "L'Osservatore Romano" (French version) 11.10.1973.

${ }^{46}$ Cf. 'Then Peter stood up'..., p. 73. 


\section{The First Theological Studies of the Catholic Understanding of the Charismatic Renewal}

Every year Cardinal Suenens published a pastoral letter to his faithful in the Diocese of Malines-Brussels. At Pentecost 1973, the traditional letter is accompanied by an appendix of several dozen pages, entitled Discovering the Holy Spirit. ${ }^{47}$ In its last part, under the subtitle What is Charismatic Renewal? Suenens explains that it is about Christians gathering in prayer, following the example of the first Christian communities. He stresses that these gatherings have

a varied physiognomy, since they are characterized by great spontaneity and are adapted to totally different environments: parishes, university environments, convents, religious orders, charitable or social groups... The deep roots of these gatherings are a living faith lived in the presence of the Lord acting through the Holy Spirit as the renewer of all life: personal, family, professional, social, political. ${ }^{48}$

The document ends by encouraging the coordination of already existing Charismatic groups in Belgium and in Europe in general. For this purpose Cardinal Suenens appoints as coordinator of these groups a priest from his diocese, Fr Wilfried Brieven. The entire document also includes a suggestion to read the first study on Charismatics, published by the French Episcopate, whose author was Fr Henry Caffarel, founder of the famous French family movement, Equipes Notre Dame. ${ }^{49}$

On May 21-26, 1974, Cardinal Suenens organised in his diocese of Malines a theological commission to work out the issues of the Charismatic Renewal movement. ${ }^{50}$ It consists of the following persons: Carlos Aldunate SJ, Salvador Carrillo MSpS, Ralph Martin, Albert de Montléon OP, Kilian McDonnell OSP, Heribert Mühlen, Veronica O'Brien, Kevin Ranaghan. A draft document describ-

${ }^{47}$ L.-J. Suenens, Redécouvrir le Saint-Esprit. Pentecôte 1973, "Pastoralia" 5, Annexe, pp. 85-99.

48 Ibid., p. 92.

49 This is the personal testimony of Fr Henry Caffarel. Since Fr. Francis Blachnicki was in close contact with Fr. Caffarel (among other things, the fruit of these contacts was the creation of the Domowy Kościół (House Church) on the model of the French Équipes Notre-Dame), it is highly probable that Fr. Blachnicki's interest in the experience of ecumenism and the Charismatic Renewal also proceeded from him.

${ }^{50}$ The Commission consisted of the following: K. McDonnell OSB (USA), K. Ranaghan (USA), Fr Aldunate SJ (Chile), Fr A. de Monléon OP (France), V. O'Brien (Ireland), Prof. H. Mühlen of Paderborn (Germany), Fr Carrillo (Mexico). The secretary of the commission was Fr Lebeau SJ. Fr Kilian McDonnell (director of the Ecumenical Institute in Collegeville [USA]) was the chief editor of the document. Cardinal Suenens' task included chairing the discussion sessions and 'taking the risk of having [the discerned proposals] recognized or rejected by Rome'. See: L.-J. Suenens, Souvenirs et Espérances..., p. 223. 
ing the new spiritual experience is created first. Consulting theologians such as Yves Congar OP, Avery Dulles SJ, Michel Hurley SJ, Walter Kasper, René Laurentin, Jospeh Ratzinger and Hans Küng, ${ }^{51}$ the document was completed and published the same year, entitled Theological and Pastoral Orientations for the Charismatic Renewal in the Catholic Church (Le Renouveau charismatique. Orientations théologiques et pastorales). ${ }^{52}$ The publication quickly became known as the First Document of Malines. ${ }^{53}$ The widespread appreciation of its contents was even confirmed by Pope Paul VI, personally conveying to Suenens: 'It is a kind of clarification, exactly what we needed: continue, please, to provide studies of this kind at the service of the Renewal. ${ }^{54}$ In all, six documents of this kind were produced..$^{55}$

The second Document of Malines, entitled Ecumenism and Charismatic Renewal (Oecuménisme et Renouveau charismatique) was written in $1978 .{ }^{56}$ The reflection of this second text concerns a wrong understanding of ecumenism and warns against confusion leading to indifferentism, proselytism or schism in the Church. The document presents a brief genesis of the Renewal movement, points to its charismatic current, specifying, however, the conditions for the authenticity of ecumenism and the Charismatic Renewal in the Roman Catholic Church. In the part entitled Pastoral orientations there is an interesting analysis of guidelines, undoubtedly still current for many Charismatic communities. ${ }^{57}$

The third Document of Malines, entitled Renewal in the Holy Spirit and Service to Man (Renouveau dans l'Esprit et service de l'homme) and published in

${ }^{51}$ Cf.: ibid., p. 216. id., Dokumenty z Malines..., p. 14.

${ }^{52}$ See: Le Renouveau charismatique. Orientations théologique et pastorales, ed. by K. McDonnell, Lumen Vitae, [s.1.] [s.a.]; translated into Polish: L.-J. Suenens, Dokumenty z Malines. Przyjdź Duchu Święty. Podstawowe dokumenty dotyczace Odnowy w Duchu Świętym w Kościele Katolickim, Kraków 1998, pp. 11-84.

${ }_{53}$ This title is linked to the place of creation, but also to the history of the famous documents of Malines from the first ecumenical dialogue with the Anglican Church, initiated by Cardinal Mercier in the 1920s.

${ }^{54}$ L.-J. Suenens, Souvenirs et Espérances..., pp. 223-224.

${ }^{55}$ Cardinal Suenens is the author or co-author of the second and subsequent publications.

${ }^{56}$ See: L.-J. Suenens, Ecuménisme et Renouveau charismatique, Le Centurion, [s.1.] [s.a.]; translated into Polish: L.-J. Suenens, Dokumenty z Malines..., pp. 85-210. $2^{\text {nd }}$ ed. in French: id., Ecuménisme et Renouveau charismatique [in:] id., L'Esprit Saint, souffle vital de l'Eglise, t. II, ed. de l'Association FIAT, Oppem-Meise, pp. 83-213.

${ }^{57}$ In the 1990 s and at the beginning of the $21^{\text {st }}$ century in Poland there were many conversions from the Catholic Charismatic Renewal communities to various Pentecostal communities. The most spectacular and painful departures were observed in such places as Kalisz (several hundred Catholics joined the evangelical community Sword of the Spirit), Racibórz, Warsaw, Wrocław, etc. Cf.: M. Dymarczyk, Na kamyku imię nowe, "Gazeta Wyborcza" 25.3.1998, pp. 20-21, 23. A. Siemieniewski, Rozłam - charyzmatyczna specjalność?, https://bit.ly/33OfYF9 [accessed: 5.10.2020]. 
1979, is a response to the criticism of the Renewal that it is not fulfilling the Christian duty to engage properly in social service. ${ }^{58}$ The document was edited jointly by Cardinal Suenens and his friend Dom Helder Câmara, Archbishop of Olinda and Recife in Brazil. The study addresses the problem of the lack of proper harmony between prayer and action of the Christian (vertical and horizontal dimensions of faith). The foundations of social involvement, resulting from the essence of Christianity, are analysed. The authors list numerous problems of the contemporary world and try to indicate their causes, as well as give suggestions for their solution. The study is full of concretes, and these arise above all from the experience of Archbishop Dom Helder Câmara, shepherd of a country of many economic contrasts and above all of poverty and misery of the majority of the population.

Another, fourth, Document of Malines: Renewal in the Holy Spirit and the Powers of Darkness (Renouveau et puissances des ténèbres) was published in 1982. ${ }^{59}$ The book addresses the issue of the incorrect use of exorcism in the environment of the Renewal and the necessity to revise the Roman Ritual for this purpose.$^{60} \mathrm{~A}$ theological analysis of the Church's attitude towards the misterium iniquitatis is included. The experience of the Renewal in relation to the problem presented here provides an opportunity to make extensive and interesting theological observations.

The fifth Document of Malines, entitled The Cult of My Self and My Faith (Le Cult du Moi et foi chrétienne), was published in $1985 .{ }^{61}$ It is a study dedicated to maintaining a proper relationship between nature and grace in the spiritual life of man. The study criticizes the excessive worship of one's self, the fruit of humanistic psychology. In the spectrum of emerging new problems among members of the Charismatic Renewal is the excessive overestimation of the role of psychology in relation to the spiritual dimension of faith and experience of the Lord God. The document warns not to relate psychological introspection of a believer (observing and analysing the subjective mental states, thoughts and reflections of the patient) to God, understood in terms of great human ideas such as Love,

58 See: L.-J. Suenens, Renouveau dans l'Esprit et service de l'homme, Lumen Vitae, Bruxelles [s.a]. Polish version of the document: id., Dokumenty z Malines..., pp. 211-296. $2^{\text {nd }}$ ed. in French: id., Renouveau dans l'Esprit et service de l'homme [in:] id., L'Esprit Saint, souffle vital de l'Eglise, t. III, éd. de l'Association FIAT, Oppem-Meise, pp. 11-107.

59 See: id., Renouveau et puissances des ténèbres, Les Cahiers du Renouveau, [s.1.] 1982; Polish version of the document: id., Dokumenty z Malines..., pp. 297-443. $2^{\text {nd }}$ ed. in French: id., Renouveau et puissances des ténèbres [in:] id., L'Esprit Saint, souffle vital de l'Eglise, t. III, éd. de l'Association FIAT, Oppem-Meise, pp. 109-215.

${ }^{60}$ Cf. id., Souvenirs et Espérances..., p. 296. The new Ritual of Exorcism, entitled Adveniat regnum tuum... has been published by the Holy See, in a model edition, only in 1999.

${ }^{61}$ See: L.-J. Suenens, Le Cult du Moi et foi chrétienne, Desclée De Brouwer, Paris 1985. Polish version of the document: id., Dokumenty z Malines..., pp. 445-536. 
Justice, Freedom. God cannot be reduced to other absolutes. Such an approach would obscure His true face. ${ }^{62}$

The sixth, and last, Document of Malines, A controversial phenomenon: Resting in the Spirit (Un phénomène controversé: le repos dans l'Esprit), published in 1986, deals with the problem of the so-called 'falling in the Spirit'. ${ }^{63}$ The analysis of the document surprisingly concludes that, due to the lack of clarity of the full spiritual meaning of this experience, it is suggested that this phenomenon should not be treated as some kind of new charism. According to the author of the text, Cardinal Suenens, resting in the Spirit is not a manifestation of the power of the Holy Spirit and therefore should not be part of the liturgy. ${ }^{64}$ This position is supported by an analysis of the historical background and by theological arguments of, among others, the German Prof. H. Mühlen, who 'believes that this phenomenon "per se" is of a psychological, therapeutic nature and is outside the religious service. ${ }^{65}$

The purpose of the Malines documents was primarily to help justify the charisms experienced and the fervour of the faith of the members of Charismatic Renewal. The documents confirmed the authenticity of this kind of living-out of the faith in the Church. ${ }^{66}$ The study, which is comprehensive in its entirety, is at the same time an important help in the constant need to discern the authenticity of the graces received. Ultimately, vigilance over the authenticity of experiences

${ }^{62}$ Cf. A.A. Kasprzak, Zagrożenie równowagi pomiędzy natura człowieka a laska Boża $w$ Odnowie $w$ Duchu Świętym $w$ kontekście psychologii humanistycznej, "Zeszyty Odnowy w Duchu Świętym” 166 (2020) 1, pp. 64-67.

${ }^{63}$ See: L.-J. Suenens, Un phénomène controversé: le repos dans l'Esprit, Desclée De Brouwer, Paris 1986 (no Polish translation). Here: $2^{\text {nd }}$ edition in French: id., Un phénomène controversé, «le repos dans l'Esprit» [in:] id., L'Esprit Saint, souffle vital de l'Eglise, t. III, éd. de l'Association FIAT, Oppem-Meise, pp. 217-259.

${ }^{64}$ See: ibid., p. 259.

${ }^{65}$ See: L.-J. Suenens, Un phénomène controversé..., p. 1. Fr René Laurentin, who in certain situations recognises repose in the Spirit as an expression of supernatural action, takes the opposite view. He does not question the possibility of God himself acting in the experience of physical relaxation that characterizes the phenomenon of 'falling in the Spirit'. In his view, such an experience seems to be justified in the situation of people exposed to great stress or anxiety, such as those in prisons or psychiatric hospitals: 'For prisoners in the terrible Mexican prisons, underground, behind bars like cages for wild animals, where they are crowded together (along with toilets without locks), psychological relaxation is then not unnecessary luxury. The same applies to residents of psychiatric hospitals, often dressed in straitjackets'. On the other hand, R. Laurentin agrees with the argument highlighted in the Malines VI document that there are indeed situations in which certain people take advantage of the experience of 'falling in the Spirit' in a systematic way, thus causing it to be abused and manipulating people for their personal gain. See: R. Laurentin, Nieznany Duch Święty. Odkrywanie Jego doświadczenia i Jego Osoby, thum. M. Sarnowska, wstęp J. Salij, Kraków 1998, p. 269.

${ }^{66}$ See: L.-J. Suenens, Souvenirs et Espérances..., p. 225. 
belongs to the shepherds of the Church and its hierarchy (cf. 1 Thessalonians 5:12. 19-21. LG 12). ${ }^{67}$

\section{The Moment of Symbolic Recognition of Charismatic Renewal by Pope Paul VI — Pentecost 1975 in St. Peter's Basilica}

On 18 May of the Jubilee Year, during the Eucharist celebrated in St Peter's Basilica, Pope Paul VI described the Charismatic Renewal as 'an opportunity for the Church and for the world' ${ }^{68}$ The event of celebrating the Feast of Pentecost in St Peter's Basilica took place as part of an organised International Conference of Charismatics. The Eucharist, presided over by Pope Paul VI, brought together some 15,000 people, 10,000 of whom were charismatics who had come for the event. ${ }^{69}$

Particularly noteworthy was the moment of greeting Pope Paul VI as he entered the basilica. Instead of the traditional form of greeting Long live the Pope! the pilgrims sang spontaneously and continuously Alleluia. ${ }^{70}$ The Holy Father welcomed everyone, pointing to their presence as hope for the Church. In his homily, he exhorted them to take care of the faith of the universal Church, but at the same time not to exalt themselves above others and to love their neighbour. It should be mentioned here that the members of the Renewal, during community prayers, expressed their joy in spontaneous shouts, applause and various invocations, including Jesus is Lord. Alleluia! The Pope surprised those gathered as he interrupted his speech with the same exclamation: Jesus is Lord. Alleluia! ${ }^{71}$

${ }^{67}$ See: Iuvenescit Ecclesia, Letter from the Congregation for the Doctrine of the Faith of 15 May 2016. Cf. A.A. Kasprzak, Lektura Iuvenescit Ecclesia listu Kongregacji Nauki Wiary z 15 maja 2016 r. oraz analiza jej głównej tezy o jedności pomiędzy darami hierarchicznymi i charyzmatycznymi, "Studia Gnesnensia" 32 (2018), pp. 227-241.

${ }^{68}$ L.-J. Suenens, Souvenirs et Espérances..., p. 234. The Pope expressed this literally (in French) in the form of a question: 'Comment alors ce « renouveau spirituel » ne pourrait-il pas être une " chance » pour l'Eglise et pour le monde?'. Paul VI, L'Homélie de Paul VI pendant la messe de la Pentecôte. "...Annoncer à tous les merveilles de Dieu... ", "Il est Vivant", n 4, juillet (1975), p. 20. Cf. “Then Peter stood up"..., p. 18.

${ }^{69}$ Among those gathered for prayer in St Peter's Basilica, a significant number of pilgrims were from other Christian denominations. They attended the event to be as friends. See: L.-J. Suenens, Souvenirs et Espérances..., p. 233.

${ }^{70}$ The exact course of these events is described by Cardinal Suenens, see: id., The Hidden Hand of God..., p. 228.

${ }^{71}$ The entire text of Pope Paul VI's speech see: Otrzymacie Jego moc. O Odnowie w Duchu Świętym, red. M.A. Babraj, Poznań 1986, pp. 53-57. B. Dembowski, Wiatr wieje tam, gdzie chce..., pp. 453-459. 
This caused great joy among those gathered and was a kind of sign of the Pope's acceptance of the characteristic colouring of the prayer of the Renewal.

The following morning, Monday after Pentecost, the aforementioned words of Veronica O'Brien's prophecy were fulfilled. The Eucharist for the Charismatics gathered in St Peter's Basilica was presided over by Cardinal Suenens. ${ }^{72}$ In his homily, a particular wish was expressed, which was later quoted many times: 'May the Charismatic Renewal disappear as such, and become a pentecostal grace for the entire Church. To be faithful to its source, the river must flow into the ocean. ${ }^{73}$ At this Eucharist, Paul VI entrusts a special concern for the Renewal to the Belgian Primate. Embracing him spontaneously and later placing his hand on his shoulder, he utters the famous words: 'I thank you, not in my own name but in the name of the Lord, for what you have done and what you will still do to bring the Renewal in the Holy Spirit into the heart of the Church. ${ }^{74}$ The public significance of the gesture and the words of Pope Paul VI towards the Charismatic Renewal and towards Cardinal Suenens, whom he then called the spiritual protector of the Renewal, can hardly be doubted. It must be stressed, however, that the official recognition of the Charismatic Renewal was much later. The recognition of the Renewal took place, paradoxically, only in 1990 and 1993. On November 11, 1990, Pope John Paul II first recognized the Catholic Confraternity of the Charismatic Renewal as a private association of the faithful. The second moment of juridical recognition came on September 14, 1993, when the Pope also recognized the statutes of the International Catholic Charismatic Renewal Services. ICCRO then changed its name to ICCRS and also received legal personality and recognition as a Private Association of the Faithful in the Church. ${ }^{75}$

72 See: L.-J. Suenens, The Hidden Hand of God..., p. 228.

${ }^{73}$ Ibid., p. 229.

74 Id., Souvenirs et Espérances..., p. 234. Cf.: id., The Hidden Hand of God..., p. 230; id., Les imprévus de Dieu..., p. 221.

75 As Bishop Paul Cordes, Episcopal Advisor to the Renewal from 1984 to 1995, points out: 'The task of the ICCRS is to promote and serve the Catholic Charismatic Renewal throughout the world "under the breath of the Holy Spirit in close contact with the Holy See". The Renewal itself being "a movement of the Spirit" has of course no legal personality. (ed)". See: P.J. Cordes, Niech Zstapi Duch Twój. Refleksje na temat Katolickiej Odnowy w Duchu Świętym, thum. S. Demska, J. Demski, Kraków 1988, pp. 18, 121. On the complex issue of the Charismatic Renewal adopting canonical status, see: the analysis M. Hébrard, Charyzmatycy..., p. 43. 


\section{Coordination - the First Structures of International Services for the Charismatic Renewal}

After Pentecost 1975, experienced at the Vatican by members of the still informal Charismatic Renewal movement in the Catholic Church, it was providential that Cardinal Suenens took the decision to invite three American leaders to work closely together: Steve Clark, Ralph Martin and Gerry Rauch. ${ }^{76}$ The realisation of this idea took place in August/September of the following year. The Primate of Belgium offered them a stay in Brussels, first in a residence located at Rue du Vallon, No. 20, 1040 Bruxelles. ${ }^{77}$ In 1980, after the retirement of Cardinal Suenens, the office was moved to the Cardinal's former residence in Brussels, at the address: 570 Boulevard De Smet de Naeyer, 1020 Bruxelles (Laken district). ${ }^{78}$ The purpose of hosting the American guests at the home of Cardinal Suenens was to form the first international coordination team of the Holy Spirit Renewal. As Cardinal Suenens underlines, it was a matter of 'continuing the dialogue between the institutional Church and the charismatic Church. ${ }^{79}$ The implementation of the intention began in 1976 and lasted until $1981 .^{80}$ The comfortable space of cooperation created under the patronage of Cardinal Suenens for the first leaders of the

${ }^{76}$ In his second autobiography, Cardinal Suenens mentions that the idea to invite American leaders of the Charismatic Renewal to Belgium came from Veronica O'Brien. The idea emerged from her spiritual inspiration received during prayer. (See: L.-J. Suenens, Les imprévus de Dieu..., p. 222). It should be noted that already earlier, that is, since 1974, Cardinal Suenens had sought to establish a francophone Charismatic Renewal in Belgium. For this purpose, the Primate of Belgium first asked the Benedictine Father Philippe Verhaegen, who already had previous experience of Baptism in the Holy Spirit in the United States, to initiate a Charismatic prayer group in Brussels. This is how the Charismatic prayer group called the Vineyard (La Vigne, in the neighbourhood near the hospital 'Aux deux Alices') was founded. The group had a great influence in the Belgian Church thanks to the frequent visits and the preaching of the Word of God by the famous Jesuit Father Paul Lebeau SJ. A second Charismatic community, also initiated by Cardinal Suenens, was founded in Lovenjoel, near Louvain-la-Neuve. Also, in 1974, Cardinal Suenens appointed the young American priest Dave Mc Keon as leader there. Sister Margy, also from the United States, was assigned to help. The community meetings were attended by the aforementioned Fr Philippe Verhaegen, as well as many prominent charismatics, such as Sr Myriam Carlier, a Poor Clare from Hannut, Sr Vincenta, a sister from the Congregation of St Vincent de Paulo. See queries: Fernand De Groote, e-mail of 1.2.2021. Cf. Philippe Verhaegen [wikipedia], https:// fr.wikipedia.org/wiki/Philippe_Verhaegen [accessed 4.2.2021].

77 American leaders of the Charismatic Renewal lived on the second floor of the building. See query: Gary Sermonik, e-mail dated 22.2.2021.

${ }^{78}$ See query: Mgr Leo Declerck, e-mail dated 16.12.2020. Cf. query: Gary Sermonik, e-mail dated 22.2.2021.

${ }^{79}$ L.-J. Suenens, Les imprévus de Dieu..., p. 222.

${ }^{80}$ The stay of the American leaders ended at different times: Steve Clark remained in Belgium until May 1978, Ralph Martin until 1980 and Gerry Rauch until 1981. See: L.-J. Suenens, Les imprévus de Dieu..., pp. 226, 229. 
Charismatic Renewal resulted in regular meetings, daily prayer and coordination in dialogue with theologians on the understanding and further development of the Charismatic Renewal in the Catholic Church. ${ }^{81}$

The hospitable residence of Cardinal Suenens in Brussels really began to fulfil what its lofty name expressed: The International Communication Office of Charismatic Renewal.$^{82}$ First established in 1972 in Ann Arbor (Michigan, USA) ${ }^{83}$ and officially moved to Brussels on 1 September 1976, the ICO coordinated the work of drafting the second and then the third document of Malines mentioned earlier, as well as continuing to publish the ICO Newsletter. In 1978, the famous Fr Tom Forrest, C.Ss.R moved to the ICO Office in Brussels from the United States, becoming its President until the office was moved to Rome. The office was also supported at this time by other numerous American Charismatics, members of such communities as: The Servants of the Word, Word of God and The People of Praise.$^{84}$ At the end of the leaders' stay in Brussels, in 1981, the office was moved to Rome, to a building in Via Ferruccio $19 .{ }^{85}$ It was then renamed The International Catholic Charismatic Renewal Office (ICCRO for short). In 1985 ICCRO was moved to the Vatican. In 1993, the name of the ICCRO was changed once more, emphasising the term 'ministry' in its title: The International Catholic Charismatic Renewal Services (ICCRS for short). ${ }^{86}$ Cardinal Suenens served as

${ }^{81}$ See: ibid., p. 232.

${ }^{82}$ Cf. D. Barett, T.M. Johnson, The Catholic Charismatic Renewal..., p. 117.

${ }^{83}$ The ICO office in the United States, in its early years (1972-1973) was moved several times. Gary Sermonik, one of Ralph Martin's collaborators in organising the ICO, explains the details of this history: 'When ICO was established, it was [first] located in the basement of the house we were renting at that time (1972-1973): 408 Thompson Street, Ann Arbor, MI 48104. However, within a year or so, we made a couple of moves until the Word of God Community acquired an old University of Michigan building called Harris Hall at 617 East Huron Street, Ann Arbor, MI 48104. The office was located there for most of its duration in Ann Arbor'. Query: Gary Sermonik, e-mail dated 22.2.2021. Cf.: ICCRS Newsletter dated 1.09.1976. See: https://dev-iccrswp. day50communications.com/en/news-newsletter/news-archive/ico-moves-to-belgium/ [accessed: 4.1.2021]. Query: Annelies Tambuyser, e-mail dated 4.1.2021.

${ }^{84}$ At the invitation of Cardinal Suenens, a group of several dozen people arrived in Belgium from the United States for a few years' stay. They came either alone or with whole families, most of them living in a house called 'Chaussée de Waterloo' in Uccle. Members of The Servants of the Word community lived in a house located in Lovenjoel near Louvain (see: supra, note 74.) See query: Gary Sermonik, e-mail dated 22.2.2021.

${ }^{85}$ See query: Annelies Tambuyser, e-mail dated 4.1.2021.

${ }^{86}$ See: B. Dembowski, Wiatr wieje tam, gdzie chce..., p. 43.

- on the structure of the ICCRS [ibid., p. 44]: 'The ICCRS is not an authority of the Renewal in the Holy Spirit, it does not govern, but it collects information and serves information and organizes joint international congresses and retreats (...)';

- on the status of the ICCRS [ibid., p. 357]: 'The Statutes of the ICCRS were approved by the Pontifical Council for the Laity on 14 September 1993. This service consists of the Office and the Council of the International Catholic Charismatic Renewal'; 
'episcopal advisor' for the Charismatic Renewal until $1984 .{ }^{87}$ The function was created for him by Pope Paul VI and was the official approval of the pastoral care of the Renewal movement.

\section{Conclusion}

Since Pentecost 2017, at the initiative of Pope Francis, the Charismatic Renewal in the Roman Catholic Church has received a new orientation. ${ }^{88}$ Pope Francis has defined, following the intuition of the Cardinal Suenens, the Charismatic Renewal as a 'Stream of Grace', also calling it by the shorthand term Charis grace in Greek. ${ }^{89}$ It is the Pope's intention to give the Catholic Renewal in the Holy Spirit even more opportunities to use its various gifts in a lived faith and, above all, lived in a more ecumenical aspect. This study confirms the historical logic of this discernment and the decision of the present pope with regard to the further orientation of the Charismatic Renewal in the Roman Catholic Church. From the very beginning of the living out of the renewed faith in Catholic Charismatics, it has been a characteristic, as Pope Paul VI emphasized already in 1973 when addressing his letter to the Charismatics gathered in Grottaferrata, that it is a specificity in which one perceives: 'the taste for deep prayer, personal and in groups, a return to contemplation and the emphasis on praise of God, the desire to devote oneself completely to Christ, an openness to the Holy Spirit, more assiduous reading of the Scriptures, generous brotherly devotion, a willingness to serve

- the ICCRS from the point of view of canon law: 'ICCRS is a JURIDICAL PERSONALITY "ad instar", i.e., corresponding to a PRIVATE ASSOCIATION ON THE FAITHFUL (Cf. CC 321-329, 116\$2)'. ICCRS STATUES, Art 2. See: 'Then Peter stood up' '..., p. 107 (pp. 105-114 - Text of the entire 1993 statutes of the ICCRS).

${ }^{87}$ Cf. P.J. Cordes, Niech Zstapi Duch Twój..., p. 3.

${ }_{88}$ The Pope's new vision has led to the formulation of new statutes for the International Service of the Catholic Charismatic Renewal. As of 9 June 2019, the ICCRS and the Catholic Confraternity of the Charismatic Renewal have ceased to exist. In their place, a new International Renewal Service henceforth named 'CHARIS' was established. This new structure acquired public juridical personality, according to canons 116-123 of the Code of Canon Law. The decision to change the name and statutes of the International Service of the Catholic Charismatic Renewal was first presented by the Dicastery for Laity, Family and Life in 2018. See: https:// charis.info.pl/sluzba-charis-statuty/ [accessed: 4.11.2020]; https://www.odnowa.org/i/charis.html [accessed: 4.11.2020] or https://bit.ly/365MEue [accessed: 4.11.2020]; https://bit.ly/ 34ZMh51 [accessed: 4.11.2020].

89 The full name of the newly created organism of international co-ordination of the Renewal in the Holy Spirit is: Catholic Charismatic Renewal International Service (Charis). See: https:// www.charis.international/en/ [accessed: 17.12.2020]. 
the Church. ${ }^{90}$ In 1986, Pope John Paul II in his encyclical on the Holy Spirit acknowledges the validity of such discernment. He states: '[...] recent years have been seeing a growth in the number of people who, in ever more widespread movements and groups, are giving first place to prayer and seeking in prayer a renewal of their spiritual life.' (JPII, Dominum et vivificantem no. 65). The special nature of the Charismatic Renewal stems from prayer, which in various Charismatic groups around the world was very often lived together with brothers and sisters from other Christian denominations, very often evangelical. This aspect is also confirmed by the present analysis: the ecumenical specificity of the Renewal in the Holy Spirit was present from the very beginning of the genesis of the lived experience of renewed faith among Catholic Charismatics.

As the first conclusion of our analysis, we would like to emphasize that this rich spiritual experience gave great joy to the adepts of the Renewal in the Holy Spirit as well as to the hierarchy of the Catholic Church. From the very beginning, the grace of the Charismatic Renewal signified a new style of Christian life, the specificity of which was at the same time its universality. Renewal touched all the people of God in a spontaneous way and thus, valued the constitutional element of the Church. ${ }^{91}$ The new experience of the Church resulted from a grassroots experience, that is, an experience which did not come about through the programmed organization of initiatives by the Church's hierarchy. The vision of the activity of the lay faithful understood in this way was in line with the perspective of the understanding of the Church by the Second Vatican Council and this was an important complement to the specificity of the activity of various movements of Catholic Action. The particular experience of the grace of the Charismatic Renewal was first witnessed by lay people through their personal lives. This experience was then confirmed by bishops and priests who, in different parts of the world, became witnesses to the same grace, often involving themselves personally in this experience as part of their vocation and various ministries. For Cardinal Suenens, the charismatic grace of the Charismatic Renewal was more than just a personal experience of faith. From the very beginning it had within it the characteristic of universality of the Church. In his opinion, the Charismatic Renewal was an answer to the Church's prayer for the grace of Pentecost. At the level of the bishops this grace was the Second Vatican Council, at the level of the lay faithful it was the Charismatic Renewal - a stream of grace that was to spread throughout the Church as the waters of a river overflew the sea.

${ }^{90}$ The entire text of Pope Paul VI's message [in:] 'Then Peter stood up'..., p. 15. Cf. L.-J. Suenens, Nowe zesłanie Ducha Świętego? ..., p. 91.

${ }^{91}$ Cf. A.A. Kasprzak, ,, Rewolucja kopernikańska” na Soborze Watykańskim II? Analiza historyczno-teologiczna redakcji drugiego rozdziału Konstytucji dogmatycznej o Kościele Lumen Gentium, o Ludzie Bożym, "Rocznik Teologii Katolickiej” 17 (2018) 3, pp. 39-52. 
The extraordinary grace of God, both of the Council and of the Charismatic Renewal, was and is not something easy and obvious to accept. As a further, second conclusion of our analysis, we want to highlight here the 'other side' of the charismatic experience in the Church, in which there is the challenge of the need for constant discernment in collaboration with the pastors of the Church. As Cardinal Suenens, Veronica O'Brien, and the first American Catholic leaders of the Renewal, including Ralph Martin, Steve Clark, Gerry Rauch, and also Pope Paul VI, perceived from the very beginning, this experience required an adapted accompaniment of the Church and thus, the creation of an appropriate structure of services. Failure to do so risked confusion, chaos and even schism in the Church. This study has shown the tremendous effort made by the Church to appoint and properly coordinate the leaders of the charismatic communities and their collaboration with the bishops and the Pope. As noted by Pope Paul VI, the burden of organising this challenge was taken on by the Primate of Belgium, Cardinal Léon-Joseph Suenens. It was on his initiative that the first space for coordinating the Renewal in the Holy Spirit within the whole universal Church was created. To this end, first, in 1976, the International Communication Office of the Charismatic Renewal (ICO) is moved from Ann Arbor to Brussels. Then, from 1981, the Office is moved to Rome, receiving the name of International Catholic Charismatic Renewal Office (ICCRO), and from 1993 - International Catholic Charismatic Renewal Services (ICCRS).

The experience of the charismatic movement in the Church needed a deeper understanding of its nature. Also, on the initiative of Cardinal Suenens, the six famous Document of Malines were produced for this purpose from 1974 to 1986. The Charismatic Renewal in the Catholic Church was symbolically recognised by Pope Paul VI in 1975. The agreement to celebrate Pentecost on 18 and 19 May of the Holy Year in St Peter's Basilica by charismatics confirmed the positive will of the Church: The Charismatic Renewal was henceforth to be at the heart of the Church. Once again Cardinal Suenens was designated by Pope Paul VI to oversee this task. The Primate of Belgium fulfilled this task as the so-called 'Episcopal Advisor', serving in this capacity at the International Office of Catholic Charismatic Renewal. The Charismatic Renewal received official recognition in two stages: first with the papal recognition on 11 November 1990 of the Catholic Confraternity of the Renewal in the Holy Spirit of the Covenant Communities and Societies as a private association of the faithful and then, on 14 September 1993, with the papal recognition of the statutes of the International Catholic Charismatic Renewal Services (ICCRS).

What about the end of the history of the Renewal in the Holy Spirit? As we said in the introduction of this analysis, the history of the Charismatic Renewal is unique. Just as it is difficult to define its beginning, there is still no reason to proclaim its end. For the renewal in the Holy Spirit has continued uninterruptedly 
for many years in all the continents of the world. It continues to bear a variety of fruits and to take up the challenges that are current for the Church, much of which is generated by the constant and dynamic changes of history. Today, the stream of grace - charis - is becoming more and more visible in the sea of the whole Church. This is how the Holy Spirit works. His grace is something living, a mystery still unknown, which hangs as if over a fractional line, like a numerator over a denominator. This grace is the motor of everything. It is this grace that transforms every cell of the Church with its immense power. But at the same time, it is invisible and silent. It is like the Gulf Stream, an underwater stream of heat - it travels thousands of kilometres in the depths of the ocean to reach the corners of the earth of its choice. Ultimately, it is not for us to decide its shape and direction. It is the Holy Spirit who decides which way He wants it to go and at what point His special grace is to be manifested. As Cardinal Suenens stressed many times towards the end of his life, God is a God of surprises (Les imprévus de Dieu) and so are His actions. It is only up to us to serve this power of God and its providences.

\section{Skomplikowany „mianownik” początków historii Odnowy w Duchu Świętym w Kościele rzymskokatolickim}

\section{Streszczenie}

Każda historia ma swój początek. Większość historii ma swój koniec. Próba syntetycznej analizy historii początku Odnowy w Duchu Świętym w Kościele rzymskokatolickim okazuje się zderzać z pewną wstępną rzeczywistością: owa historia nie tylko nie ma konkretnego początku, lecz także nie ma swojego zakończenia. To historia wciąż otwarta. Obchodząc niedawno (2017 r.) jej pięćdziesiąte urodziny w Kościele rzymskokatolickim, przyjęto za datę pierwotnego odniesienia doświadczenie de facto tylko symboliczne. Dzień otrzymania charyzmatów przez członków niewielkiej grupy amerykańskich studentów 18 lutego 1967 r. w Pittsburghu (Pensylwania) w Stanach Zjednoczonych to data i miejsce tylko umowne. Ani ów moment, ani owo wydarzenie nie wyczerpują bowiem ogromnego i o wiele rozleglejszego charyzmatycznego doświadczenia Ducha Świętego w Kościele, które można dostrzec w różnych i licznych momentach historii Kościoła. Niniejsze studium podejmuje próbę wyjaśnienia owego jednostkowego doświadczenia z perspektywy analizy istotnych elementów pierwszej strukturyzacji charyzmatycznego odrodzenia w Kościele rzymskokatolickim w XX w. Studium to jest też próbą syntetycznego spojrzenia na historię wydarzeń, jak również na tworzących ją autorów, m.in. Ralpha Martina, Steve’a Clarka, Gerry’ego Raucha, Weronikę O’Brien, kardynała Léona-Jospeha Suenensa i papieża Pawła VI. 


\section{Słowa kluczowe}

kardynał Léon-Joseph Suenens, Weronika O’Brien, papież Paweł VI, Ralph Martin, Steve Clark, Gerry Rauch, Odnowa charyzmatyczna, pentekostalizacja chrześcijaństwa, charis

\section{Keywords}

Cardinal Léon-Joseph Suenens, Veronica O’Brien, Pope Paul VI, Ralph Martin, Steve Clark, Gerry Rauch, Charismatic renewal, Pentecostalization of Christianity, charis

\section{Abbreviations}

ETL - Ephemerides Theologicae Lovanienses

ICI - Informations Catholiques Internationales

\section{Bibliography}

Barett D., Johnson T.M., The Catholic charismatic Renewal, 1959-2025 [in:] 'Then Peter stood up. 'Collection of the Popes'Addresses to the Catholic Charismatic Renewal from its origin to the year 2000, ed. by O. Pesare, ICCRS, Rome 2000.

Benelli G., « Monsieur le Cardinal », letter from Cardinal Benelli to Cardinal Suenens of 7.07.1973 [in:] Fonds L.-J. Suenens AAM, Charismatic Renewal.

Benelli G., «Monsieur le Cardinal», letter from Cardinal G. Benelli to Cardinal L.-J. Suenens of 17.09.1973 (reference number of the Secretariat of State n. 238971) [in:] Fonds L.-J. Suenens AAM, Charismatic Renewal.

Catta H.M., Peyrous B., Ogień i nadzieja. Piotr Goursat. Założyciel wspólnoty Emmanuel, thum. M. Bartnicka-Gustowska, Wyd. Esprit, Kraków 2008.

Cordes P.J., Niech Zstapi Duch Twój. Refleksje na temat Katolickiej Odnowy w Duchu Świętym, tłum. S. Demska, J. Demski, Wyd. „m”, Kraków 1988.

Declerck L., Catalogue des Archives Personnelles du cardinal L.-J. Suenens. (En dehors des papiers conciliaires et des papiers concernant la question du 'Birth Control' et de l'Encyclique 'Humanae Vitae'), 2003, Pro manuscripto. Consultation réservée.

Dembowski B., Wiatr wieje tam, gdzie chce. Z doświadczeń Odnowy w Duchu Świętym, Wyd. „m”, Kraków 1998.

Donnelly D., Author of Reform: The Cardinal Suenens Story [Documentary film], John Carroll University, 1999.

Dymarczyk M., Na kamyku imię nowe, "Gazeta Wyborcza" 25.3.1998, pp. 20-21, 23.

FConc. Suenens nr 2922-2925. See: the inventory of the post-conciliar archives of Cardinal Suenens: Declerck L., Inventaire des Papiers conciliaires du cardinal L.-J. Suenens. Addenda, [s.1.], [s.e.], 1999.

Gallagher Mansfield P., As by a New Pentecost. The Dramatic Beginning of the Catholic Charismatic Renewal, Amor Deus Publishing, Phoenix $2016^{2}$ [Originally published in 1992 by Franciscan University of Steubenville, Steubenville, OH 43952]. 
Gallagher Mansfield P., Jakby nowa Pięćdziesiątnica. Początek katolickiej Odnowy w Duchu Świętym, tłum. J. Bartosik, Wyd. Księży Marianów, Warszawa 1993.

Hébrard M., Charyzmatycy. Zarys historii Odnowy w Duchu Świętym. Fakty, postacie, wydarzenia, wspólnoty, tłum. T. Jania, Wyd. „m”, Kraków 1994.

https://bit.ly/ 34ZMh51 Original website name: http://www.zeszytyodnowy.eu/index. php/79-archiwum/3-162-2019/571-wizja-dla-wspolczesnej-katolickiej-odnowy-charyzmatycznej-michelle-moran

https://bit.ly/2IQm00G Original website name: https://zenit.org/2015/07/08/pope-s-address-to-charismatic-renewal/

https://bit.ly/34id4st Original website name: https://fr.zenit.org/articles/renouveau-charismatique-catholique-hommage-a-veronica-o-brien/

https://bit.ly/365MEue Original website name: https:/ekai.pl/powstanie-miedzynarodowa-sluzba-katolickiej-odnowy-charyzmatycznej/

https://charis.info.pl/sluzba-charis-statuty/

https://www.charis.international/en/

https://www.odnowa.org/i/charis.html

Iuvenescit Ecclesia, Letter from the Congregation for the Doctrine of the Faith of 15 May 2016.

Kasprzak A.A., Kościół a nowoczesność. Rozeznanie pastoralne przemian społeczno-kulturowych we Francji po Soborze Watykańskim II, Wydawnictwo WAM, Kraków 2018.

Kasprzak A.A., La fameuse interview du cardinal Léon-Joseph Suenens du 15 mai 1969. L'appel aux medias pour promouvoir l'autorité coresponsable et collégiale de l'Eglise, ETL 92 (2016) 3, pp. 439-468.

Kasprzak A.A., La Légion de Marie et la vision de l'Église tout entière en état de mission, idée maîtresse de la réflexion et de l'action du cardinal Léon-Joseph Suenens, ETL 95 (2019) 1, pp. 114-115.

Kasprzak A.A., Lektura Iuvenescit Ecclesia listu Kongregacji Nauki Wiary z 15 maja 2016 r. oraz analiza jej głównej tezy o jedności pomiędzy darami hierarchicznymi i charyzmatycznymi, "Studia Gnesnensia" 32 (2018), pp. 227-241.

Kasprzak A.A., ,, Rewolucja kopernikańska” na Soborze Watykańskim II? Analiza historyczno-teologiczna redakcji drugiego rozdziału Konstytucji dogmatycznej o Kościele Lumen Gentium, o Ludzie Bożym, "Rocznik Teologii Katolickiej” 17 (2018) 3, pp. 39-52.

Kasprzak A.A., Teologiczne podstawy Odnowy w Duchu Świętym w ujęciu kardynała Léona Josepha Suenensa, WT UAM, Poznań 1999.

Kasprzak A.A., Zagrożenie równowagi pomiędzy naturą człowieka a łaska Bożą w Odnowie $w$ Duchu Świętym w kontekście psychologii humanistycznej, "Zeszyty Odnowy w Duchu Świętym” 166 (2020) 1, pp. 64-67.

Laurentin R., Nieznany Duch Święty. Odkrywanie Jego doświadczenia i Jego Osoby, tłum. M. Sarnowska, wstęp J. Salij, Wyd. Znak, Kraków 1998. 
Le Renouveau charismatique. Orientations théologique et pastorales, éd. McDonnell, Lumen Vitae, [s.1.] [s.a.]; thum. na j. pol. L.-J. Suenens, Dokumenty z Malines. Przyjdź Duchu Święty. Podstawowe dokumenty dotyczace Odnowy w Duchu Świętym w Kościele Katolickim, tłum. Wydawnictwo „m”, Kraków 1998, pp. 11-84.

Matthys R., Le Cardinal Suenens et le feu de la Pentecôte, 2 pp. Document in own archives.

Nowicka M., Nowicki M., Upili się młodym winem, Początki Odnowy w Duchu Świętym $w$ Polsce (1975-1979), Wyd. Swidermajer, 2016 ( $2^{\text {nd }}$ ed.), Warszawa.

Otrzymacie Jego moc. O Odnowie w Duchu Świętym, red. M.A. Babraj, W drodze, Poznań 1986.

Paul VI, L'Homélie de Paul VI pendant la messe de la Pentecôte. « ...Annoncer à tous les merveilles de Dieu... », "Il est Vivant", n 4, juillet (1975), pp. 17-21.

Philippe Verhaegen [Wikipedia], https://fr.wikipedia.org/wiki/Philippe_Verhaegen.

Query: Annelies Tambuyser, E-mail dated 4.1.2021.

Query: Fernand De Groote, E-mail dated 1.2.2021.

Query: Gary Sermonik, E-mail dated 22.2.2021.

Query: Mgr Leo Declerck, E-mail dated 12.6.2019.

Query: Mgr Leo Declerck, E-mail dated 16.12.2020.

Query: Mgr Wilfried Brieven, E-mail dated 4.6.2019.

Routhier G., Vatican II. Herméneutique et réception, Ed. Fides, Québec 2006.

[S.A.], ICO Moves to Belgium, ICO Newsletter, September 1976, https://dev-iccrswp. day50communications.com/en/news-newsletter/news-archive/ico-moves-to-belgium/.

[S.A.], Powotanie do Wspólnoty Emmanuel. Formacja, Wspólnota Emmanuel, Warszawa 2021.

Siemieniewski A., Rozłam - charyzmatyczna specjalność? https://rzymski-katolik. blogspot.com/2015/04/ks-andrzej-siemieniewski-rozam.html.

Suenens L.-J., A New Pentecost?, A Crossroad Book — The Seabury Press, New York 1975.

Suenens L.-J., Dar dla Kościoła, “Zeszyty Odnowy w Duchu Świętym” 16 (1997).

Suenens L.-J., Dar Odnowy a postuga kapłana izakonnika. I Ogólnopolski Kongres Odnowy w Duchu Świętym. Jasna Góra - Sala Papieska 14 X 1983. Cassette No. 4. p. A and B (comprehensive set prepared by Mr Jacek Fedorowicz) [in:] A.A. Kasprzak, Teologiczne podstawy Odnowy w Duchu Świętym w ujęciu kardynała Léona Josepha Suenensa [Master's dissertation], WT UAM, Poznań 1999, pp. 44-45 (for the full text of the conference see: appendix p. 148, cf. CD: track no. 3).

Suenens L.-J., Dokumenty z Malines. Przyjdź Duchu Święty. Podstawowe dokumenty dotyczące Odnowy w Duchu Świętym w Kościele katolickim, tłum. W. Kustra, A. Kowalski, A. Liduchowska, A. Rozwadowska, T. Micewicz, Wydawnictwo „m”, Kraków 1998.

Suenens L.-J., La Coresponsabilité dans l'Église d'aujourd'hui, Desclée De Brouwer, Bruges 1968. 
Suenens L.-J., Le Cult du Moi et foi chrétienne, Desclée De Brouwer, Paris 1985. Polish version of the document: id., Dokumenty z Malines..., pp. 445-536. The publishing house of the FIAT Association of Belgium has not undertaken to reprint this document in its three-volume new series of Malines Documents.

Suenens L.-J., Les imprévus de Dieu, Fayard, Paris 1993.

Suenens L.-J., Les imprévus de Dieu, "Bonne Nouvelle" VII-X (1993), pp. 4-5.

Suenens L.-J., L'unité de l'Église dans la logique de Vatican II [Interview accordée à José de Broucker], ICI 336 (15.V.1969), pp. I-XVI. Translation of the interview into Polish: id., Logiczne konsekwencje Soboru: Wywiad z kardynatem Suenensem, "Tygodnik Powszechny” 22 (1.VI.1969), pp. 1, 3-4.

Suenens L.-J., Nowe zesłanie Ducha Świętego?, W drodze, Poznań 1988.

Suenens L.-J., Ecuménisme et Renouveau charismatique, Le Centurion, [s.1.] [s.a.]; Polish version of the document: id., Dokumenty $z$ Malines..., pp. 85-210. $2^{\text {nd }}$ ed. in French: id., CEcuménisme et Renouveau charismatique [in:] id., L'Esprit Saint, souffle vital de l'Eglise, t. II, éd. de l'Association FIAT, Oppem-Meise, pp. 83-213.

Suenens L.-J., Redécouvrir le Saint-Esprit. Pentecôte 1973, "Pastoralia", n 5, Annexe, pp. 85-99.

Suenens L.-J., Renouveau dans l'Esprit et service de l'homme, Lumen Vitae, Bruxelles [s.a]. Polish version of the document: id., Dokumenty z Malines..., pp. 211-296. $2^{\text {nd }}$ ed. in French: id., Renouveau dans l'Esprit et service de l'homme [in:] id., L'Esprit Saint, souffle vital de l'Eglise, t. III, éd. de l'Association FIAT, OppemMeise, pp. 11-107.

Suenens L.-J., Renouveau et puissances des ténèbres, Les Cahiers du Renouveau, [s.1.] 1982; Polish version of the document: id., Dokumenty z Malines..., pp. 297-443. $2^{\text {nd }}$ ed. in French: id., Renouveau et puissances des ténèbres [in:] id., L'Esprit Saint, souffle vital de l'Eglise, t. III, éd. de l'Association FIAT, Oppem-Meise, pp. 109215.

Suenens L.-J., Souvenirs et Espérances, Libraire Arthème Fayard, Paris 1991.

Suenens L.-J., The Hidden Hand of God: The Life of Veronica O'Brien and our Common Apostolate, Veritas, Dublin 1994.

Suenens L.-J., “Très Saint Père...”, letter from Cardinal Suenens to Pope Paul VI, 24.07.1973 [in:] Fonds L.-J. Suenens AAM, Charismatic Renewal.

Suenens L.-J., Un phénomène controversé: le repos dans l'Esprit. Desclée De Brouwer, Paris 1986. Here: $2^{\text {nd }}$ ed. in French: id., Un phénomène controversé, «le repos dans l'Esprit » [in:] id., L'Esprit Saint, souffle vital de l'Eglise, t. III, éd. de l'Association FIAT, Oppem-Meise, pp. 217-259.

'Then Peter stood up.' Collection of the Popes'Addresses to the Catholic Charismatic Renewal from its origin to the year 2000, ed. by O. Pesare, ICCRS, Rome 2000.

Tomczyk D., Kościół katolicki wobec ruchu odnowy charyzmatycznej, "Collectanea Theologica" 57 (1987) 1, pp. 45-60. 